SOUZA, Juliana Teixeira. Carne podre, café com milho e leite com água: disputas de autoridade e fiscalização do comércio de gêneros na Corte imperial, 1840-1889. História, Ciências, Saúde Manguinhos, Rio de Janeiro, v.18, n.4, out.-dez. 2011, p.1039-1056.

\title{
Carne podre, café com milho e leite com água: disputas de autoridade e fiscalização do comércio de gêneros na Corte imperial, 1840-1889*
}

\section{Rotten meat, coffee with corn, and watered-down milk: power struggles and oversight of the food trade in the Imperial Court, 1840-1889}

\author{
Juliana Teixeira Souza \\ Professora adjunta do Departamento de História/ \\ Universidade Federal do Rio Grande do Norte. \\ Campus Universitário Lagoa Nova \\ BR 101, s/n \\ 59072-970 - Natal - RN - Brasil \\ julianasouza@cchla.ufrn.br
}

Recebido para publicação em março de 2010. Aprovado para publicação em fevereiro de 2011

\section{Resumo}

Durante o Segundo Reinado, a regulamentação e a fiscalização do comércio de gêneros na cidade do Rio de Janeiro foram marcadas por intensos conflitos envolvendo a Câmara Municipal, a Secretaria de Polícia e a Junta Central de Higiene, cujas atribuições se sobrepunham no tocante a essa questão. $\mathrm{O}$ artigo analisa os enfrentamentos entre esses órgãos, considerando as confusões de competências e as disputas de autoridade e enfatizando o esforço da instituição camarária em manter suas antigas atribuições quanto à saúde pública, aspecto fundamental para a preservação de sua capacidade de intervenção governativa.

Palavras-chave: comércio de alimentos; fiscalização de posturas; Câmara Municipal do Rio de Janeiro (Brasil); Junta Central de Higiene Pública; Secretaria de Polícia.

\section{Abstract}

During the Second Reign, the regulation and inspection of food trade in the city of Rio de Janeiro were characterized by heated clashes between three agencies that had overlapping powers in the matter: the Câmara Municipal (Municipal Chambers), the Secretaria de Polícia (Police Department), and the Junta Central de Higiene Pública (Central Public Hygiene Board). The article analyzes the conflicts between these agencies, while taking into account their coincidental duties and power disputes and also underscoring the Chamber's effort to preserve its former public health responsibilities, essential to protecting its governmental capacities.

Keywords: food trade; enforcement of municipal ordinances; Câmara Municipal do Rio de Janeiro; Junta Central de Higiene Pública; Secretaria de Polícia. 


\section{Saúde pública e polícia dos mercados}

Em 26 de fevereiro de 1857, o jornal Correio Mercantil noticiou que "o fiscal do Sacramento multou a dois benzedores de leite e a um açougueiro que vendia carne podre". As autoridades responsáveis pelo flagrante não tinham dúvidas de que recaía sobre os comerciantes a culpa pela grande incidência de produtos com qualidade duvidosa sendo comercializados na capital do Império. Essa certeza, compartilhada por boa parte da população consumidora, aparece confirmada na mesma folha desse periódico, no seguinte informe: "O subde-legado da freguesia da Candelária, na correição a que procedeu anteontem em parte do seu distrito, acompanhado do médico da polícia, o Sr. Dr. José Francisco de Souza Lemos, visitou 24 casas de negócio, e multou a Antonio Ferreira de Castro, morador no Arco do Telles n. 6, por vender café com milho torrado e ter sua casa com falta de asseio". Essas e outras tantas notícias publicadas nos periódicos da época mostram que nas casas de comércio, bancas de mercado ou entre vendedores ambulantes não era difícil encontrar carne podre, peixe cheirando mal, café triturado com milho, leite com água, vinho misturado com corantes ou substâncias que lhe tiravam a acidez e tudo mais que a criatividade pudesse inventar, com vistas a permitir que pequenos negociantes aumentassem suas margens de lucro ou evitassem o prejuízo de desfazer-se dos produtos deteriorados. Práticas contumazes, no Rio de Janeiro do século XIX, a venda de produtos falsificados e a negociação de gêneros em condições impróprias para o consumo se destacavam dentre as infrações mais cometidas pelos comerciantes do ramo alimentício.

As penas impostas àqueles que cometessem esses delitos eram determinadas pelo Código de Posturas da Câmara Municipal, a quem competia contribuir para a manutenção da segurança e tranquilidade públicas, organizar o espaço urbano, cuidar da saúde pública e regular a economia local. ${ }^{1}$ De acordo com as posturas, seriam multados os indivíduos que vendessem quaisquer gêneros corrompidos ou falsificados, estando sujeitos à prisão nos casos de reincidência.

Em geral, eram os fiscais de freguesia que ficavam incumbidos de avaliar a condição e composição dos alimentos, embora não dispusessem de nenhuma formação ou habilidade específicas que os credenciasse mais do que qualquer outro indivíduo para o exercício dessa função. Na primeira metade do século XIX, acreditava-se que identificar um gênero corrompido ou falsificado era tarefa que não exigia conhecimento diferente daquele proporcionado pelo senso comum, ou pelo bom senso, e era isso que se esperava dos fiscais. Para ocupar o cargo, bastava saber ler, escrever e ter idoneidade reconhecida (Abreu, 1999, p.194). Supunha-se que o aperfeiçoamento na execução de suas atribuições fosse proporcionado pelo tempo de exercício do ofício. De modo algum, isso significava que as avaliações dos fiscais de freguesia não fossem passíveis de contestação. Por serem comuns os protestos, os fiscais procuravam reforçar a validade de seus pareceres, em geral buscando o apoio da população consumidora. Particularmente nas ocasiões em que eram chamados a esclarecer sua conduta diante de uma autoridade superior, costumavam mencionar o testemunho da população para amparar seu julgamento, na expectativa de que a aprovação dos cidadãos lhes fosse suficiente para atestar sua competência. Esse foi o procedimento adotado por Joaquim José Tavares, fiscal da freguesia do Sacramento, quando se viu obrigado 
a justificar, perante os vereadores, a pena que havia imposto dias antes ao dono de uma quitanda. Em seu ofício ele relatou:

No dia 19 do corrente às 5 horas da tarde, percorrendo o distrito de minha freguesia, encontrei na casa de quitanda miúda de Fernando Calisto, (que se acha preso pelo chefe de polícia por faltas que cometera), uma porção de carne seca em putrefação, a qual mandei imediatamente lançar à rua, a fim de que as pessoas que passassem e vissem seu mau estado, e depois mandei conduzir a mesma, em carroças e cabeças de pretos, e arrojála ao mar. A carne toda teria de peso cento e vinte arrobas, pouco mais ou menos, e cumprindo assim o disposto no mencionado parágrafo, autuei o dito Fernando Calisto (Documentos..., 22 jan. 1842). ${ }^{2}$

As posturas informavam que carnes ou peixes danificados deveriam ser prontamente enterrados ou lançados ao mar (Código de Posturas..., 1870, p.26). Nesse sentido, ao decidir expor a carne aos passantes antes de jogá-la ao mar, Joaquim José Tavares evidenciou a importância que conferia à opinião pública na legitimação de suas decisões, revelando também alguns aspectos da vida política da cidade. Ao que parece, pelo simples fato de consentir ou reprovar publicamente as ações dos fiscais de freguesia, a população reforçava ou solapava sua autoridade de acordo com seus interesses, conforme a atenção e o encaminhamento dado pelas autoridades públicas às suas demandas, o que obrigava os fiscais a manterem-se atentos às suas expectativas.

A população esperava que os fiscais, além de interpretarem e darem cumprimento às posturas, ouvissem suas queixas sobre venda de alimentos deteriorados, suspeita de alteração na composição dos alimentos, fumaça que saía das chaminés das padarias, falta de higiene de alguns estabelecimentos e outros atentados contra a salubridade pública. Transitando entre o Paço Municipal e a rua, onde se relacionavam com outros grupos de agentes que de maneira informal interferiam no ordenamento da vida social, era essencial, para os fiscais de freguesia, contar com a aprovação e o respaldo dos munícipes, até porque os comerciantes insatisfeitos com as multas que lhes eram impostas não eram os únicos a questionar a autoridade e a competência dos funcionários da municipalidade no exercício de atribuições ligadas à saúde pública.

O decreto de 3 de dezembro de 1841, responsável pela reformulação do Código do Processo Criminal, foi instrumento fundamental para a centralização do poder pretendida pelo Regresso conservador, movimento que consolidou os saquaremas à frente do Estado imperial. O decreto criou uma hierarquia paralela de funcionários policiais submetidos ao chefe de polícia, escolhido pelo imperador e diretamente subordinado ao ministro da Justiça (Mattos, 2004). A partir de então, a Secretaria de Polícia da Corte ficaria encarregada de providenciar, entre outras ações, o cumprimento dos assuntos de polícia previstos no Código de Posturas, seção em que estavam incluídos vários parágrafos sobre questões como ofensas menores da ordem pública, edificações, vacinas e polícia dos mercados. Esse dispositivo resultou na sobreposição das jurisdições da Câmara e da Secretaria.

No entanto, como o decreto restringiu a atuação da polícia à prevenção e repressão dos artigos incluídos na Seção Segunda - Polícia do Código de Posturas -, a investida do governo central sobre a esfera de atuação da Câmara obteve resultados parciais. Afinal, a instituição camarária preservara suas funções deliberativas e mantivera atribuições exclusivas sobre as 
demais matérias tratadas no Código de Posturas, inscritas na Seção Primeira - Saúde Pública. Por conta disso, nas décadas que se seguiram à reformulação do Código do Processo Criminal, percebe-se o esforço contínuo da Secretaria para alargar seu campo de ação, pretendendo exclusividade sobre um conjunto variado de competências (Bourdieu, 1989³). Os chefes de polícia procuravam, por um lado, estabelecer sua hegemonia na administração dos assuntos de polícia esvaziando a autoridade das outras instituições que atuavam nesse setor e, por outro, estender sua atribuição sobre os temas relacionados à saúde pública.

Alegando que a vereança não cumpria suas obrigações de maneira apropriada, o chefe de polícia Antonio Simões da Silva defendeu essa proposta junto ao ministro da Justiça, Eusébio de Queirós Coutinho Matoso, em relatório de 13 de novembro de 1849:

\begin{abstract}
Não é minha intenção entrar no exame aprofundado da propriedade, e mesmo competência das Câmaras Municipais para certos objetos, desejo apenas fazer sentir a Vossa Excelência a necessidade de uma Lei que dê à Polícia algumas atribuições das Câmaras Municipais, principalmente as que ela exerce com mais impropriedade. A ação fraca, e improfícua, que elas têm sobre as Escolas, Médicos, Cirurgiões, Boticários, sobre Hospitais, Casas de Saúde, moléstias contagiosas etc. e sobre muitas outras coisas de igual importância, é mais prejudicial, do que útil, porque habitua o povo a olhar com pouco respeito para essas disposições sem dúvida legais, mas que não tendo utilidade por mal concebidas, e pior desenvolvidas, ele julga poder infringi-las, e o mais é que por uma correlação mal entendida aplica o mesmo falso raciocínio a tudo quanto é restrição legal (Silva, 13 nov. 1849).
\end{abstract}

Nos dias de hoje, pode parecer estranho um chefe de polícia pleitear o direito de examinar, fiscalizar e resolver questões que habitualmente relacionamos ao campo da saúde. No entanto, é preciso ter em conta que, àquela altura, a polícia e tampouco os médicos haviam estabelecido os limites de seu campo, sendo fluidos os critérios quanto ao que estava dentro ou fora da alçada de cada segmento profissional. Para a Secretaria de Polícia, as possibilidades se multiplicavam, posto que nem o controle sobre o processo de produção e aplicação dos saberes médicos estava assegurado (Sampaio, 2001). Se a pretensão da polícia era determinar, com exclusividade, as diretrizes das políticas públicas de controle social, com direito a tomar decisões, dar ordens e agir como considerasse conveniente para se fazer obedecer a respeito dos mais variados aspectos da vida cotidiana dos habitantes da cidade, a estratégia de estender seu raio de ação aos problemas relativos à saúde pública parecia muito apropriada.

Ao analisar o conteúdo da legislação municipal, verificamos que os pontos tratados sob esse título não se limitavam a enterros, cemitérios, hospitais e moléstias contagiosas. Na Seção Primeira - Saúde Pública - das posturas havia disposições sobre venda de alimentos e remédios, estabelecimento e asseio de currais e matadouros, aterramento de áreas pantanosas, estabelecimento de curtumes, funcionamento de fábricas e manufaturas, entre outros. Tratava-se, portanto, de tópicos estreitamente relacionados a produção, comércio e ocupação do espaço, que sob a jurisdição da municipalidade permitiam à vereança decidir sobre pontos estratégicos da economia da maior e mais rica cidade da América do Sul.

Em um contexto em que a medicina despontava como elemento central nas políticas de controle social, não escapava ao chefe de polícia Antonio Simões da Silva a soma de poder e autoridade que poderia ser granjeada pela instituição que conquistasse o direito de regular 
os assuntos referentes à saúde pública (Foucault, 1985). Portanto, o que estava em jogo não era apenas a habilidade de a vereança e a polícia cuidarem com mais ou menos propriedade da matéria. Importava, em grande medida, a possibilidade de a Secretaria agregar um novo domínio ao seu campo de atuação, aumentando sua capacidade de implementar uma política eficaz de controle e vigilância sobre a população. Para a Câmara interessava, naturalmente, preservar esse domínio contra as investidas dos agentes de outras esferas do poder de Estado que concorriam para o esvaziamento de sua autoridade local.

Contudo, apesar dos esforços de Antonio Simões da Silva, os bacharéis da polícia não conseguiram fazer frente às estratégias que vinham sendo postas em ação pelos próprios médicos (Herschmann, Kropf, Nunes, 1996; Coelho, 1999). Mesmo que as dificuldades na delimitação de seu campo fossem evidentes e eles estivessem longe de resolver suas divergências sobre procedimentos, técnicas ou mesmo a constituição de seus saberes, com a criação da Junta Central de Higiene ${ }^{4}$, em 1850, esses profissionais estabeleceram um caminho seguro para participar mais ativamente da definição das políticas de controle social impostas pelo Estado, passo relevante na busca de prestígio e reconhecimento no âmbito da administração pública empreendida pelos médicos. Algumas das atribuições do novo órgão se sobrepunham às da Câmara, obrigando os médicos a compartilharem, com a vereança, responsabilidades como fiscalização de drogarias e boticas, vigilância das fábricas e inspeção dos alimentos. A vereança, contrariada com a criação de mais uma instituição subordinada ao governo central, que, assim como a Secretaria de Polícia, tinha pretensão de consolidar sua autoridade à custa do esvaziamento da instituição camarária, viu-se obrigada a lutar em várias frentes para preservar suas tradicionais atribuições, sem abrir mão de dar a última palavra sobre a saúde e economia do município. ${ }^{5}$

\section{A atuação da Câmara Municipal}

Na sessão de 5 de março de 1853, o presidente interino da Câmara Municipal e outros vereadores apresentaram aos colegas uma proposta de reforma dos meios de execução das posturas, com vistas a estabelecer uma fiscalização mais eficiente sobre a venda de gêneros alimentícios. O documento expõe as obrigações dos vereadores e seu compromisso com o bem-estar e a defesa dos interesses das classes pobres, cuja saúde física e financeira parecia continuamente prejudicada pela falta de escrúpulos por parte do corpo de comerciantes.

Um dos deveres que devemos ter por mais santos, e mais dignos de nós, é por certo aquele que se dirige a aliviar um dos muitos vexames que desgraçadamente pesam sobre as damas pobres da sociedade.

Não há aí quem não sinta, quem não veja cotidianamente as falsificações que muitas dessas casas, vulgarmente chamadas Vendas ou Tabernas - praticam em detrimento da pobreza, e como meio de levantar em pouco tempo fortunas que muitas vezes têm até chegado a ser colossais. Ali se falsificam o peso e a medida. Ali se altera à vontade, ou se vendem os gêneros de primeira necessidade em tal estado de corrupção que mais se podem chamar veneno do que alimento para o pobre operário. Diga-o a avultada cifra de óbitos por lesões intestinais, e outras enfermidades de sua natural consequência, que lentamente vão ceifando uma boa parte dessa numerosa classe (Documentos..., cód. 59-1-45, 5 mar. 1853). 
Ainda que endossasse as expectativas dos trabalhadores pobres, que incessantemente reclamavam do costume dos comerciantes de vender alimentos impróprios para o consumo, esse discurso não pode ser lido apenas como uma defesa dos direitos do povo. Antes de tudo, o documento foi redigido para reforçar a autoridade da instituição camarária, pois se os vereadores negassem seu dever de proteger as damas e os operários sujeitos àquelas fraudes e abusos, estariam expostos ao risco de ter a legitimidade de seu governo questionada. Por conta disso, sua preocupação foi reconhecer o problema e tentar aquietar a torrente de reclamações que a opinião pública vinha dirigindo à vereança, com a promessa de fiscalização mais rigorosa dali em diante.

É interessante notar que os vereadores tiveram o cuidado de se dirigir especialmente às mulheres pobres. Com efeito, elas desempenhavam um papel de destaque nas relações de mercado, por lidar diretamente com os comerciantes, barganhar o preço das mercadorias ou averiguar pessoalmente a qualidade dos produtos expostos à venda (Dias, 1984). Essas práticas proporcionavam às mulheres larga experiência na detecção de produtos deteriorados, falsificados ou vendidos com peso inferior ao estipulado (Thompson, 2002, p.184). Portanto, elas eram capazes de identificar tanto os comerciantes que agiam de má-fé quanto as autoridades que não cumpriam corretamente suas obrigações na vigilância e autuação dos contraventores, o que as tornava figuras primordiais no trabalho de fiscalização informal do comércio a retalho.

Os vereadores procuraram ainda demonstrar que os problemas atribuídos à incompetência da Câmara poderiam ser resolvidos mediante algumas mudanças na execução da fiscalização. Nesse ponto do documento, dirigiram-se aos grupos de agentes com os quais concorriam pelo domínio sobre aquele setor da administração pública, em vez de aos municípes:

Diz-nos-ão talvez que nem as leis existentes são suficientes, nem os seus naturais executores são os mais azados para obstar o mal. Falsa doutrina é essa ... Então, com um fim muito especial, clamava-se contra a mais pequena ação de um Juiz Almotacel, que se prejudicava a um beneficiava a muitos. Hoje tolera-se o lucro criminoso de poucos com grave e visível malefício de todos. ... Nem se diga que essas ideias são retrógradas, e que como tais devem ser banidas da discussão. O verdadeiro progresso não pode ser avaliado por palavras mas sim pela experiência .... E como estejam convencidos de que o defeito não está tanto na deficiência das leis vigentes como na falta de aplicação moral de uma grande parte de seus executores; " têm a honra de propor o seguinte:

O vereador encarregado de cada Freguesia fica autorizado a fazer nela as correções que julgar conveniente, em companhia do Fiscal respectivo e seus Guardas, com o fim de inspecionar tudo quanto possa ser relativo ao interesse da saúde pública, e ao bem-estar da classe pobre da sociedade, somando-se neste ato de todos os meios que a Lei lhe facultar.

A menção às atribuições exercidas pela almotaçaria foi o caminho encontrado pelos vereadores para recordar aos seus adversários as prerrogativas tradicionalmente desempenhadas pelas câmaras municipais desde o Antigo Regime (Monteiro, 1998; Gouvêa, 2002), se não desde tempos ainda mais longínquos (Pereira, 2001). O propósito era reforçar o fato de que a municipalidade cuidava das questões ligadas à saúde pública e à economia 
local havia várias gerações e que essa experiência lhe proporcionara um conhecimento que não poderia ser apreendido prontamente por outros órgãos. Enquanto os bacharéis de direito e medicina se apresentavam como os senhores do progresso e da eficiência, lutando para introduzir novas categorias de percepção do mundo social, o discurso dos vereadores evocava um passado remoto e idealizado, regido por valores morais que acreditavam compartilhados por todo o conjunto social. Ao assumir a defesa desses valores que propunham resgatar, procuravam convencer a população de que estariam mais bem capacitados do que qualquer outro agente do governo para providenciar o ordenamento da vida citadina, arrogando-se o papel de legítimos protetores da classe pobre e de naturais executores da justiça e do bem comum.

$\mathrm{Na}$ prática, a proposta dos vereadores não alterava de maneira significativa a forma como a instituição camarária vinha tratando da fiscalização do cumprimento das posturas. Com a decisão de se unirem aos fiscais nas correições, no entanto, os vereadores buscavam estabelecer um contato mais direto com os munícipes, estreitando a relação entre governantes e governados, tornando mais visível a figura e, concomitantemente, a autoridade desses homens. Em nota marginal ao documento encaminhado para votação, verificamos que a proposta foi aprovada pelos demais membros da Câmara em 11 de junho de 1853, sem dificuldades.

Para a população consumidora, talvez importasse pouco saber qual instituição estaria encarregada de fiscalizar a qualidade dos produtos expostos à venda, desde que fosse constatada sua eficiência e, preferencialmente, que comerciantes infratores fossem multados e presos. O governo central e a municipalidade, porém, estavam longe de chegar a um consenso sobre a jurisdição de cada órgão e sobre a relação de subordinação entre eles. Segundo a Secretaria de Polícia, a vereança era incapaz de prevenir e reprimir de forma eficiente as infrações cometidas pelos comerciantes. Na opinião dos membros da Junta Central de Higiene, os funcionários da municipalidade não eram capazes de emitir juízo correto e aceitável sobre a qualidade e a composição dos alimentos vistoriados. Em comum, Secretaria e Junta aspiravam a estabelecer instâncias externas de controle sobre a instituição camarária ou mesmo a substituí-la (Chalhoub, 1996).

As pretensões dos bacharéis da Secretaria e dos médicos da Junta esbarravam, entretanto, na organização administrativa do Estado imperial. A sobreposição de atribuições dos órgãos ligados ao governo central às tradicionais competências da Câmara Municipal impedia que cada instituição se orientasse de acordo com o que a distinguia e definia de modo exclusivo. Embora nas décadas de 1840 e 1850 se tenha consolidado a hegemonia dos dirigentes saquaremas, com política fortemente voltada para a centralização do poder, A Câmara Municipal, sob o pretexto de cumprir o antigo regimento das câmaras de 1828 e o Código de Posturas, pôde preservar aspectos fundamentais de seu poder e autoridade, definindo políticas públicas para setores estratégicos da administração, zelando pela saúde pública, ordenando o espaço urbano e regulando as atividades econômicas da cidade mais próspera do Império.

O capital político e simbólico angariado pelos concorrentes ainda não lhes permitia dispor de poder tão extenso. As atribuições juridicamente asseguradas à Câmara eram essenciais para reforçar seu poder, pois uma vez que o Estado sanciona as leis, ele fixa 
hierarquias e consagra relações entre os agentes sociais (Bourdieu, 1989). Além disso, para a consolidação de sua autoridade, a instituição camarária recorria ao prestígio e à reputação acumulados no passado, no tempo em que fora cabeça do Império colonial português (Gouvêa, 1998) e que desempenhara papel-chave na consolidação do Brasil independente (Souza, 1999).

Os médicos, mais especificamente, tinham sérias dificuldades em consolidar a reputação da categoria, tendo que lidar com frequentes questionamentos sobre sua competência, em grande parte decorrentes do fraco desempenho no exercício da arte de curar e da pouca confiabilidade no resultado de suas técnicas e seus procedimentos. Essa fragilidade não era ignorada pelos agentes da municipalidade. Os fiscais eram especialmente pródigos em desqualificar o saber médico, avaliando eles mesmos as condições dos gêneros vendidos no mercado varejista. A diferença estava no fato de seu discurso não ter qualquer atributo científico, mesmo que ambicionasse ser igualmente reconhecido como verdadeiro. Com a experiência adquirida no trabalho cotidiano, os fiscais tinham métodos próprios para julgar a qualidade dos alimentos e os continuaram empregando a despeito de toda crítica dirigida pelos médicos aos saberes informais. Além disso, é preciso ter em conta que, apesar de as atribuições da Junta e da Secretaria se confundirem com a esfera de atuação da Câmara, os fiscais da municipalidade ainda eram os primeiros encarregados de "vigiar a observância das posturas da Câmara, promovendo a sua execução pela advertência aos que forem obrigados a elas, ou particularmente ou por meio de editais", conforme determinação expressa no artigo 85 do Regimento das Câmaras de 1828.

Porque fiscalizavam os delitos cometidos em prejuízo da saúde pública há mais tempo que os agentes de outras instituições, os fiscais eram mais facilmente reconhecidos pela população como responsáveis pela defesa daquilo que compreendiam como seus direitos. As manifestações de aprovação ao seu trabalho eram esparsas, mas acontecia de um ou outro fiscal ter suas qualidades exaltadas nas páginas dos jornais. João José Alves Ferreira, fiscal da freguesia de Santana, conquistou comentários elogiosos numa carta publicada no Correio da Tarde em 7 de fevereiro de 1856. Em seu favor, o leitor, que assinou Um do Povo, escreveu:

Se a Ilustríssima Câmara tivesse muitos empregados tão ativos e zelosos como o Sr. Ferreira, fiscal de Santana, estou certo de que as coisas andariam de outra maneira, e que o povo não chamaria imposturas as posturas da municipalidade, tão desprezadas têm sido elas, já pelo desleixo, já pelo patronato. ... Assim o vimos multando a um eleitor popular, que vendia ao povo café torrado misturado com milho, a um capitão da guarda nacional, condecorado com diversas ordens honoríficas, grande proprietário, que, por seus escravos, mandava vender ao povo leite falsificado, esquecidos de que serviam cargos populares e de que, em uma quadra tão lastimosa, deviam antes abrir suas recheadas bolsas do que especular em detrimento da saúde pública, dando veneno aos míseros, a quem deviam fazer esmolas - sacra auri fames (grifos do original).

Não podemos descartar a hipótese de ter sido o próprio fiscal a escrever a carta, mesmo porque há traços comuns entre esse relato e outros ofícios emitidos pelos vereadores, em que eles se mostravam continuamente preocupados em endossar as queixas e reivindicações da população no tocante à regulamentação do mercado, e procuravam assegurar 
reiteradamente o compromisso de defender seus interesses. Ainda que seja esse o caso, justamente para se fazer crer como Um do Povo, o autor da carta opera com crenças, valores e expectativas com os quais o público leitor e a população de forma geral pudessem identificar-se, o que pode ser verificado nos elementos que compõem a narrativa.

Apesar do empenho dos agentes da municipalidade em convencer a população de que as posturas da cidade eram um instrumento eficaz de defesa dos direitos e do bem-estar dos munícipes, havia uma desconfiança, tenazmente negada, de laços escusos entre os governantes e o corpo de comerciantes da cidade. Por isso, atitudes mais contundentes na repressão aos infratores causavam grande impressão nos ânimos de quem esperava que o poder público efetivamente cumprisse o dever moral de proteger as classes menos favorecidas. Ao explicar os motivos que o levaram a publicar aquela carta, Um do Povo explicitou a indignação da população consumidora a cada tentativa frustrada de flagrante, mostrando como isso contribuía para aumentar as expectativas da população quanto à atuação das autoridades municipais:

Estávamos à janela pela madrugada, como de antigo e invariável costume, à espera de um vendedor de leite. O primeiro, que passou com sua vaquinha de amostra, recusou vender-nos meia pataca de leite, ordenhado à nossa vista, declarando que só vendia o contido nas vasilhas, e depois de alguma disputa continuou o seu caminho, mas, oh desgraça!... sai-lhe ao encontro o zeloso fiscal, que procedendo ao exame da mistura que nos queria o ilhéu nos impingir por leite, mandou-o despejar na rua por falsificado! E estes especuladores, sem embargo destes quase cotidianos exames, não se escarmentam, dando assim a crer que os lucros que tiram vendendo gato por lebre são tais, que os compensam e indenizam das repetidas multas: vejam daqui que tal não é a ganância!

Ao solicitar que a vaca fosse ordenhada à sua vista, o consumidor tentava assegurar que levaria para casa leite fresco e puro. Sua decisão seria justificada pela suspeita generalizada de que os vendedores de leite vinham explorando o costume de carregar vasilhas com leite adulterado, misturado à água e outras substâncias. Inicialmente, o propósito de trazer o leite em recipientes era agilizar a compra do produto, mas havia indícios de que alguns vendedores utilizavam esse expediente para encobrir a comercialização de leite 'benzido'. A cautela de Um do Povo devia parecer ainda mais procedente, uma vez que o vendedor insistia em negociar apenas o produto contido nas vasilhas e recusava-se a ordenhar a vaca que trazia consigo. Não obstante Um do Povo quisesse adquirir leite seguramente puro, no relato prevaleceu a estratégia do vendedor, que não era obrigado a tirar o leite em sua presença. Daí a figura do fiscal ser enaltecida como o guardião da justiça, pois se não estivesse próximo ao local para tomar a iniciativa de averiguar o motivo da recusa, outros consumidores se veriam diante das opções de comprar leite suspeito ou voltar para casa de mãos vazias.

Cumpre destacar que, no relato, não há menção ao método utilizado para determinar a falsificação do leite, embora ele tenha sido despejado na rua sob essa alegação. Supõe-se que o fiscal João José Alves Ferreira tenha realizado o exame no local, tomando sua decisão com base em observações de textura, coloração, sabor ou odor do leite, como era comum. Nesse caso, ele só poderia utilizar como critério de avaliação o conhecimento adquirido com a prática cotidiana daquele ofício, posto que uma análise adequada da composição do produto poderia ser efetuada apenas em laboratório. 
Ainda que parte dos consumidores depositasse grande confiança nas avaliações dos fiscais, isso não os resguardava de enfrentamentos com os comerciantes insatisfeitos com o hábito de fazerem desaparecer toda mercadoria que desconfiassem corrompidas ou falsificadas. Lembramos que, exceto nos casos de carne e peixe, os gêneros suspeitos deveriam ser conduzidos ao depósito público, o contrário se constituindo arbitrariedade. Nesses casos, restava aos comerciantes tentar desqualificar os métodos empregados pelos fiscais e os pareceres por eles emitidos, o que costumavam fazer requisitando a opinião de especialistas, apropriando-se de seu discurso e valorizando suas técnicas.

O fiscal João José Alves Ferreira ignorou as queixas dos vendedores de leite, mas parece que um deles fez com que seus métodos de ação fossem publicamente questionados. Em denúncia publicada no Diário do Rio de Janeiro, em 7 de fevereiro de 1856, o fiscal da freguesia de Santana foi acusado de prender escravos por venderem leite falsificado sem provas concretas de que a infração tivesse ocorrido. A resposta veio no dia seguinte, na seção Publicações a Pedido do Correio Mercantil:

O fiscal da freguesia de Santana declara ao respeitável público que ainda não prendeu pessoa alguma por vender leite falsificado, senão depois do exame feito pelos srs. boticários Benedito José de Araújo, Flávio José da Silva e Francisco Antonio de Castro, e declararem estes a falsificação, como procedeu ultimamente a respeito do escravo de uma alta personagem, que, com seus próprios olhos, se convenceu da justiça e circunspeção do seu procedimento.

João José Alves Ferreira não ignorava a inconsistência dos seus métodos de análise. A rigor, mesmo que acreditasse que os conhecimentos acumulados ao longo dos anos lhe dessem condições de determinar verdadeiramente se um alimento estava corrompido ou falsificado, ele não estava habilitado a executar esse tipo de análise. Por conta disso, em sua defesa recorreu ao respaldo dos boticários. O fato de reconhecer que essa habilidade cabia a uma determinada categoria profissional mostra que o fiscal admitia os limites impostos por seu lugar de fala e percebia a profunda mudança que se vinha processando nas regras de formação dos enunciados aceitos como verdadeiros. Eram regras que ele desconhecia e cujo acesso estava restrito àqueles que alcançavam determinado nível de educação formal; por esse motivo, o Estado atribuía aos boticários o exame dos gêneros suspeitos.

O episódio, porém, não demoveu o fiscal de sua jornada contra os vendedores de leite falsificado. Apesar das queixas, continuou despejando nas ruas todo produto trazido em vasilhas que não lhe inspirassem confiança, com ou sem o exame dos boticários. Como as condições em que eram flagrados os supostos infratores se repetissem, um ano e muitas multas depois ele tomou a iniciativa de enviar à Câmara Municipal uma proposta que, no seu entendimento, limitaria a ação dos "benzedores de leite". Sugeriu que os ambulantes fossem "privados dessa vasilha, que lhes serve de escudo ao seu dolo, a sua perfídia" (Documentos..., cód. 58-4-45, 20 fev. 1857). Para satisfação do fiscal, seu pedido foi aprovado pela instituição camarária em 3 de abril de 1857, sendo reiterado em outras ocasiões (Documentos..., cód. 58-4-45, 2 abr. 1869).

A decisão indicou que a vereança aprovava o empenho de João José Alves Ferreira na repressão à venda de leite falsificado, ainda que seus métodos contrariassem os comerciantes 
e subestimassem a importância das análises de laboratório sobre a qualidade e composição dos alimentos. Dessa forma, mesmo sem desqualificar o saber acadêmico de forma direta, a Câmara reforçou a credibilidade dos fiscais em detrimento de outros profissionais, em clara tentativa de conter o esvaziamento de suas atribuições, esteio do poder e autoridade que a instituição camarária lutava para preservar.

\section{Competências sobrepostas}

À medida que as práticas da Secretaria de Polícia da Corte se voltaram cada vez mais para o patrulhamento das ruas e a condução de processos judiciais (Holloway, 1997), as disputas pela jurisdição dos assuntos relativos à saúde pública e regulamentação da economia local passaram a restringir-se à Câmara e à Junta, cujos funcionários estavam encarregados de inspecionar os mercados e casas comerciais da cidade. A percepção geral sobre essas comissões não era das mais positivas, e o problema chegou a ser comentado no Correio da Tarde, em 19 de setembro de 1855:

As comissões sanitárias das diferentes freguesias não funcionam de acordo com a autoridade municipal. Os empregados da municipalidade puxam para um lado, os da polícia para outro: a polícia é feita (quando se faz) a arbítrio de cada um no que respeita ao asseio e salubridade pública; as comissões não se entendem convenientemente com a polícia administrativa, e com a municipal!

Isto ainda não é tudo. Vende-se ao povo carne fresca deteriorada, como se tem clamado pela imprensa; as espeluncas de comidas feitas continuam com toda sua imundície; as tavernas são ainda o que sempre foram, apesar das visitas que uma ou outra vez lhes faz a polícia.

De acordo com os decretos que organizaram o funcionamento da Junta Central de Higiene, ficou mesmo estabelecido que a fiscalização das posturas referentes à saúde pública seria feita por comissões compostas por fiscais e médicos, devidamente acompanhados por guardas municipais, uma espécie de força policial auxiliar. No entanto, quando obrigados a atuar juntos, os membros da Junta e os fiscais da municipalidade não costumavam pautar-se pelo espírito de cooperação. Como era de esperar, a convivência forçada entre agentes de setores concorrentes da administração pública tendia a acirrar suas disputas. Embora não fosse explicitado, o risco de boicote motivava o encaminhamento de ofícios como o dirigido pelo doutor Francisco de Paula Cândido ao presidente da Câmara Municipal:

Tendo os Membros da Junta Central de Higiene Pública de proceder, na conformidade do aviso do Ministro do Império do 11 do corrente mês, às visitas diárias em todas as casas e mercados que expõem a venda gêneros alimentícios: rogo a Vossa Excelência, em cumprimento do mesmo Aviso, haja de expedir as convenientes ordens para que os Fiscais da Ilustríssima Câmara Municipal se prestem a acompanhar os Membros da Junta nas visitas a que haverem de proceder, a fim de fazerem efetivas as disposições das Posturas Municipais (Documentos..., cód. 59-1-45, 13 abr. 1860).

Em atendendimento ao pedido, o presidente da Câmara Municipal providenciou para que todos os fiscais fossem informados da determinação ministerial. No entanto, o aviso 
não assegurava que as relações entre os funcionários desses órgãos fossem cordiais. A dificuldade de entrosamento se agravava, posto que os fiscais não aceitavam de bom grado o fato de os profissionais da área da saúde estarem em condição de executar procedimentos que eles, por serem leigos, não estavam habilitados a reproduzir ou avaliar. $\mathrm{O}$ ressentimento poderia ser exacerbado pela ação dos comerciantes, que, a par dos atritos que marcavam a relação entre médicos e fiscais, não poupavam esforços para intensificá-los a fim de tirar algum proveito da situação. Observamos isso num caso ocorrido em julho de 1865 . Na ocasião, o comerciante Antonio Cardoso Souza, proprietário de um estabelecimento na freguesia de Santana, foi multado por vender goiabada estragada. Quem avaliou a qualidade do produto foi um delegado da Junta Central de Higiene, mas o comerciante discordou de seu parecer e decidiu recorrer ao presidente da Câmara com a seguinte alegação:

\begin{abstract}
Ao suplicante, Ilustríssimo Senhor, foi tolhida a defesa mandando-se lançar no mangue as latas apreendidas contra o expresso no parágrafo $1^{\circ}$ título $2^{\circ}$ do Código de Posturas que manda recolher ao depósito público os objetos sobre os quais versa a multa, salvo carne ou peixe. O suplicante pode provar com pessoas gradas da vizinhança e fregueses do estabelecimento que nunca vendeu gêneros deteriorados e menos goiabada corrompida como em Vossa Senhoria espera achar a justiça reta que Vossa Senhoria costuma fazer, e atendendo a que o suplicante não se pode defender por falta da matéria-prima, vem respeitosamente requerer a Vossa Senhoria se digne absolver o suplicante da injusta multa que recebeu.
\end{abstract}

Com a presente petição não tem o suplicante em vista, nem de leve ferir o senhor fiscal nem dele queixar-se, pois sabe perfeitamente que Sua Senhoria não é profissional nestes termos (Documentos..., cód. 9-2-19, jul. 1865).

Com muita propriedade, o comerciante mostrou que o hábito de fazer sumir toda mercadoria sob suspeita diminuía consideravelmente a margem de manobra daqueles que desejavam provar sua inocência, pois não haveria amostra do produto para proceder à contraprova. Dessa forma, ficava a palavra do responsável pela autuação contra a do suposto infrator, numa situação em que os agentes do Estado contavam desfrutar de maior crédito. Na queixa apresentada pelo dono de quitanda percebe-se também que, em sua opinião, havia uma diferença muito clara entre a execução da lei e o poder exercido de forma arbitrária, já que ele considerou que a ação da comissão infringia determinações exaradas nas posturas. Sua argumentação parece ajustar-se às proposições de Thompson (1997) sobre o fato de que, por ter a lei lógica própria, sua aplicação deveria obedecer a determinadas regras e procedimentos para que parecesse justa. A transgressão dessa lógica e dessas regras foi o que impediu o negociante de se defender nos foros legais, fato que constituía grave violação de seus direitos. A multa que lhe fora imposta, portanto, parecia fruto de uma injustiça, que a seu ver a instituição camarária estaria obrigada a reparar, já que fora autuado por infração às posturas municipais.

Conforme habitualmente procedia em caso de queixa ou reclamação, o presidente da Câmara consultou o fiscal daquela freguesia sobre o caso. No entanto, apesar da preocupação do queixoso em inocentar o fiscal de qualquer responsabilidade sobre o ocorrido, ele não conquistou a simpatia do agente do Estado, que anexou à reclamação do dono da quitanda o seguinte ofício: 
A multa aplicada ao suplicante, segundo marca o parágrafo 1o, Título II, Seção Primeira das Posturas, fora muito justa, enquanto ele suplicante alega injustiça, isso para mim não é estranho porque não há um só infrator que diga que foi justa a multa.

Do médico não se pode supor injustiça, pois antes eu o achava muito condescendente, e as suas qualidades estão muito acima de qualquer suposição do suplicante, só em casos idênticos ao do suplicante é que ele pedia aplicação do parágrafo acima, enquanto o suplicante dizer que sente o doce não esteja em depósito, como marca o parágrafo 1 , título $2^{\circ}$, de provar sua justiça, estou certo que se ele estivesse em depósito o suplicante não faria tal petição, porque as provas estavam presentes. E sobre o suplicante dizer que do fiscal não se queixa por não ser profissional, também não precisava ser médico para se conhecer que uma porção de doce dilacerado e com bichos era podre, basta somente ter olhos e olfato, nada mais.

O fiscal procurou desconstruir o argumento do comerciante, ao colocar em perspectiva a definição de justiça e defender que a opinião sobre o que é verdadeiramente justo pode variar conforme a formação e a condição dos indivíduos, as circunstâncias em que se encontram e os interesses em jogo. Se, diante da violação dos seus direitos, o comerciante reivindicava o cumprimento direto e objetivo da lei, o fiscal apelava para os sofismas, até porque contava com menos evidências a seu favor. Afinal, a goiabada deveria ter ido para o depósito público. Mesmo assim, o fato de o fiscal justificar o procedimento adotado pelo membro da Junta não indica que o estivesse propriamente defendendo.

Nas últimas linhas do documento, evidencia-se o profundo descontentamento do fiscal com o comentário do comerciante sobre ele não ser um profissional da saúde. O dono da quitanda alegou que esse campo de atuação era dos médicos, que possuíam um saber e um título que os fiscais não detinham. Ao indicar que não era preciso ser nenhum especialista para constatar que a goiabada estava estragada, bastando que qualquer pessoa com capacidade de discernimento tivesse contato com o produto para chegar à mesma conclusão a que chegara o membro da Junta, o fiscal desvalorizou o saber médico, equiparando-o ao senso comum. A despeito disso, a assertiva do comerciante indica que o discurso dos médicos era objeto de grande difusão e consumo, o que ocorreu de maneira mais intensa na segunda metade do século XIX, situação que punha em risco crescente a posição dos fiscais, continuamente desautorizados a emitir qualquer juízo sobre saúde pública.

Com a progressiva valorização dos saberes científicos em detrimento dos saberes empíricos, foi por terra a pretensão dos vereadores de preservarem as antigas atribuições de seus subordinados. Os fiscais, apesar de serem obrigados a acompanhar os membros da Junta em suas inspeções, autuando os comerciantes que aqueles apontavam como infratores, ou seja, cumprindo suas ordens, não admitiam serem desrespeitados ou menosprezados pelos médicos. Quando percebiam que os membros da Junta não lhes dispensavam a devida consideração, faziam questão de lhes provar que ainda exerciam uma função estratégica no ordenamento das atividades econômicas locais, podendo mesmo causar grande embaraço aos agentes de outras instituições. Foi o que mostrou o fiscal José Marques Florião ao chefe da Comissão Sanitária da Candelária.

Em abril de 1882, o médico da Comissão Sanitária da Candelária informou ao presidente da Junta Central de Higiene que, após percorrer a Praça do Mercado e condenar "o peixe que encontrou alterado, e frutas verdes, dirigiu-se ao Fiscal da Freguesia, para que 
providenciasse, no sentido da remoção; e como lhe foi negado esse serviço e mais um dos guardas para acompanhá-la", decidira reportar o caso a seu superior para que procedesse da forma conveniente (Documentos..., cód. 59-1-46, 6 abr. 1882; cópia de doc. anexo). O caso foi encaminhado ao presidente da Câmara, que exigiu do fiscal esclarecimentos sobre o caso. Este, como esperado, apresentou outra versão para o incidente. Segundo ele, tendo o jornal Gazeta de Notícias chamado sua atenção para a pretensão de alguns comerciantes venderem peixe alterado ou posto em gelo por muitos dias durante a Semana Santa, decidira colocar guardas em locais estratégicos do mercado, para prevenir e reprimir possíveis infrações. Ao saber que um dos guardas abandonara seu posto para acompanhar a Comissão Sanitária, ordenou que ele voltasse a cumprir suas ordens, "porque, se a Comissão precisava do serviço do guarda, teria se entendido comigo". Pouco tempo depois, os membros da Comissão apareceram e ordenaram-lhe que mandasse pôr no vazadouro o peixe que traziam num cesto. Nesse ponto, escreveu o fiscal: "perguntei-lhes por que e quem pagava esse carreto, obtive em resposta que eu. Obrigaram então a dizer-lhes que não estava autorizado a tanto". Na conclusão de seu relatório ao presidente da Câmara, o fiscal ainda afirmou:

\begin{abstract}
Tenho escritório na Praça do Mercado, ali estou cedo, retiro-me tarde, rondo a freguesia e neste tirocínio vou ao escritório 4, 5, 6 vezes por dia; a Comissão podia procurar-me ou escrever-me para qualquer serviço. Em que com este procedimento a Comissão quebrava a sua dignidade? ... sei perfeitamente os deveres fiscais e policiais, para que sejam coadjuvadas as Comissões, não me furtei a desempenhar os meus deveres, porém desejava que fosse dentro da órbita das minhas funções e sempre respeitando-se o prestígio do empregado (Documentos..., cód. 59-1-46, 6 abr. 1882).
\end{abstract}

Era verdade que, enquanto durassem as correições, os fiscais se limitavam a meros executores das determinações expedidas pelos médicos da Junta, cabendo-lhes tão somente lavrar os autos de infração de posturas e tomar providências quanto às mercadorias condenadas pelos médicos. Exigiam, contudo, que os médicos da Junta não os confundissem com seus subordinados, pois sem a emissão dos autos, a imposição de multas e o recolhimento das mercadorias consideradas impróprias para o consumo, não havia como os médicos punirem os delitos praticados pelos comerciantes, em prejuízo da saúde pública. Ou seja, sem o auxílio dos fiscais as atividades práticas das comissões sanitárias ficavam bastante restritas, assim como seu poder de ordenar e se fazer obedecer junto à população. Ciente das limitações da Junta e do papel que desempenhava no ordenamento do comércio varejista, o fiscal fez crer que os membros da Comissão deveriam tê-lo prestigiado, requisitando seu auxílio de maneira mais amistosa ou menos altiva, talvez o consultando sobre a forma mais conveniente de executar aquela tarefa, para que não exorbitassem das suas atribuições e para que ele não fosse prejudicado no cumprimento de suas funções rotineiras.

Além disso, uma ordem tout court só poderia ser dirigida a um subordinado, e o fiscal não se considerava obrigado, naquela ocasião, a se colocar sob as ordens da Comissão, posto que seu auxílio não fora requisitado da maneira que ele considerava apropriada. Ao ser tratado como subalterno pelos médicos, que ainda passaram por cima das ordens que expedira aos guardas sob seu serviço, o fiscal José Marques Florião se sentiu duplamente ofendido. A interrupção abrupta de seus serviços para o cumprimento de ordens oriundas de outra esfera do poder e as contraordens expedidas pelos médicos junto aos guardas 
foram consideradas uma afronta a sua autoridade. Inconformado, o fiscal teve a preocupação de lembrar ao presidente da Câmara que seu dever era apenas coadjuvar as comissões, expressão empregada de forma muito precisa, pois coadjuvar remetia à ideia de ajuda mútua e reciprocidade, e a seu ver não foram esses os princípios que nortearam as ações do presidente da Comissão Sanitária da Candelária.

Aos médicos parecia justificável se sobreporem aos fiscais, que não detinham os saberes técnico-científicos apropriados para promover uma vigilância eficaz dos assuntos ligados à saúde pública - como se aos leigos coubesse apenas cumprir as determinações dos mais qualificados. Contudo, não era essa a perspectiva dos membros da Câmara. Ao deliberarem sobre a queixa apresentada pelo médico da Junta, os vereadores se limitaram a emitir breve nota marginal ao documento, mandando que o fiscal atendesse às requisições das comissões sanitárias, "de acordo com as Posturas" (Documentos..., cód. 59-1-46, 20 abr. 1882; nota marginal). Foi uma curta ressalva, sem dúvida, mas evidencia que, não obstante as comissões tivessem o direito de requisitar auxílio da municipalidade, antes de tudo os fiscais eram funcionários da Câmara, estavam subordinados à vereança e sua principal atribuição era cumprir as posturas municipais, não as ordens de outras esferas do poder.

\section{O saber médico como aporte do poder municipal}

Na década de 1880, diante do crescente aumento do prestígio e da reputação dos médicos, os vereadores ainda tentaram restituir aos fiscais a prerrogativa de emitir juízos sobre a qualidade de alguns alimentos, para que pudessem proceder a suas inspeções sem recorrer às análises dos profissionais especializados. Para tanto, solicitaram ao doutor Albuquerque Dinis que fornecesse aos fiscais uma base de conhecimentos que lhes permitisse avaliar a qualidade do leite vendido nas ruas da cidade. Como os resultados práticos das técnicas utilizadas pelos médicos ainda fossem questionáveis, a vereança considerou possível resgatar parte das atribuições perdidas por seus funcionários, submetendo-os a uma espécie de capacitação que os dispensasse do ingresso numa instituição de ensino. Contudo, as pretensões da Câmara foram tolhidas pelo doutor Albuquerque Dinis:

Em virtude da resolução contida na Ata da Ilustríssima Câmara Municipal, publicada no Jornal do Commercio de hoje, em que me autoriza fornecer base aos fiscais para conhecimento do leite ... Para que se possa ter esta base, e segura, solicito da Ilustríssima Câmara que por intermédio do Ministério do Império se consiga que o leite em questão seja examinado no Laboratório de Higiene, a cargo do Dr. Borges da Costa, com o fim de se poder conhecer a sua qualidade.

É impossível que os fiscais possam emitir juízo seguro sobre a qualidade do leite, cuja análise exige conhecimento especial, e neste caso é prudente que os fiscais remetam o leite que julgarem falsificados para ser observado no referido laboratório (Documentos..., cód. 59-1-17, 20 jan. 1884).

O crédito acumulado pelos médicos nas décadas anteriores se deveu, essencialmente, ao monopólio de um saber que só poderia ser adquirido por meio de uma educação formal, à custa de grande investimento. Logo, poderíamos deduzir que poucos médicos aceitariam sem resistência a ideia de que meia dúzia de instruções bastasse para habilitar um leigo a 
reproduzir seus procedimentos de análise, pois se cada campo se orienta por aquilo que o distingue de modo exclusivo não seria apropriado tornar os fiscais peritos num domínio que tinham como próprio. Embora o parecer do doutor Albuquerque Dinis tenha-se encaminhado nesse sentido, tal raciocínio só poderia ser generalizado se os médicos formassem uma categoria coesa e lutassem por interesses comuns, mas esse não era o caso.

Entre os nove vereadores que tomaram posse naquele ano, seis eram médicos, e foram eles que elaboraram a proposta. Isso evidencia o compromisso daqueles homens com os interesses da instituição à qual estavam vinculados, mesmo que resultasse em desvalorização do saber médico e questionamento quanto a seu domínio sobre os assuntos relacionados à saúde pública. Para os vereadores, fossem eles médicos ou não, o importante era impedir que a função dos fiscais fosse esvaziada e suas atribuições continuassem sendo progressivamente assumidas por agentes de outras instituições, visto que era por meio de seu trabalho diário, percorrendo as ruas da cidade, atuando decisivamente sobre os modos de viver e ganhar a vida, que a instituição camarária se fazia próxima e presente na vida de boa parte da população.

Por outro lado, a resposta de Albuquerque Dinis e sua aceitação por parte da vereança mostram que, apesar da precariedade do saber médico, um longo caminho havia sido percorrido desde a criação da Junta Central de Higiene. Àquela altura, diferentemente das décadas de 1850 e 1860, a categoria podia contar com a consolidação de suas técnicas e seus procedimentos de análise como instrumento eficaz nas políticas públicas de controle social, tornando-se importante fator de governabilidade, com diversos órgãos a amparar as decisões informadas pelos juízos emitidos por esses profissionais. Na década de 1880, tendo ficado evidente que não poderia prescindir das atividades práticas dos médicos para executar suas políticas de saúde pública, restou à vereança incorporar esses profissionais a seus quadros e explorar os recursos que eles disponibilizavam em favor da Câmara Municipal. Essa inflexão pode ser observada nos avisos que passaram a ser expedidos pela vereança aos fiscais de freguesia, com disposições como a que segue:

\footnotetext{
De ordem do Excelentíssimo Senhor Doutor Presidente da Ilustríssima Câmara, queiram Vossas Senhorias quanto antes proceder a correção em todas as casas de negócio, como tavernas, casas de pasto, de quitanda, usando de todo rigor contra todas aquelas que tiverem gêneros alimentícios deteriorados, frutas verdes, podres, \& e bem assim que visitem todos os cortiços, casas de alugar quartos etc., aconselhando e exigindo a maior limpeza possível, sendo acompanhados os mesmos fiscais de médicos desta Câmara (Documentos..., cód. 59-1-46, 12 nov. 1886).
}

Com a orientação para os fiscais exercerem suas atividades acompanhados pelos médicos da municipalidade, a atuação desses profissionais deixava de representar risco para se converter em reforço da capacidade de intervenção governativa da vereança. O essencial era que a Câmara Municipal preservasse suas antigas atribuições, continuando a dar a última palavra sobre as políticas de saúde pública implantadas no município.

\section{NOTAS}

* Este artigo baseia-se em minha tese de doutorado em história, A autoridade municipal na Corte imperial: enfrentamentos e negociações na regulação do comércio de gêneros (1840-1889), orientada por Silvia Hunold 
Lara e apresentada à Universidade Estadual de Campinas (Souza, 2007), tendo contado com financiamento do CNPq e Fapesp. Agradeço especialmente os comentários e sugestões de Jefferson Cano, Maria de Fátima Silva Gouvêa, Martha Abreu e Sidney Chalhoub.

${ }^{1}$ Utilizo o texto editado em 1870 com o Código de Posturas de 1838, que vigorou até o período republicano, e as dezenas de editais que lhe foram acrescentadas posteriormente.

${ }^{2}$ Uma vez que o objetivo central de minha tese era analisar, na rotina administrativa camarária, discursos e práticas que evidenciassem a preocupação dos vereadores em preservar as antigas atribuições da municipalidade, privilegiei a documentação produzida pela Câmara Municipal. Para a análise dos conflitos entre a municipalidade e a Junta Central de Higiene, com ênfase na atuação da Junta, ver Chalhoub, 1996.

${ }^{3}$ Ver especialmente "A gênese dos conceitos de habitus e de campo", em Bourdieu, 1989.

${ }^{4}$ A Junta Central de Higiene foi extinta em fevereiro de 1886 e sucedida pela Inspetoria Geral de Higiene.

${ }^{5}$ Embora regular e vigiar as ofensas menores da ordem pública fosse um das atribuições fundamentais da Câmara Municipal, sobretudo entre as décadas de 1830 e 1870, considero atribuições tradicionais da Câmara as disposições relacionadas a regulamentação da economia local, políticas de saúde pública e ordenamento do espaço urbano, que correspondem ao que Magnus Roberto de Mello Pereira (2001) identificou como as atribuições básicas do direito de almotaçaria, exercido pelas câmaras municipais portuguesas desde o final do medievo: o controle do mercado, do sanitário e do edificatório. A importância do controle sobre o mercado é reforçada por Maria de Fátima Silva Gouvêa (2002) em estudo sobre o exercício do poder e a autoridade da Câmara Municipal do Rio de Janeiro, no período de 1780 a 1820, em que destaca a relevância da jurisdição desse órgão sobre a organização de cerimônias festivas e de listas de homens habilitados a ocupar cargos de governança, como também sobre a gestão do abastecimento de carne na cidade.

\section{REFERÊNCIAS}

ABREU, Martha.

O império do divino: festas religiosas e cultura popular no Rio de Janeiro, 1830-1900. Rio de Janeiro: Nova Fronteira. 1999.

BOURDIEU, Pierre.

O poder simbólico. Lisboa: Difel. 1989.

CHALHOUB, Sidney.

Cidade febril: cortiços e epidemias na Corte imperial. São Paulo: Companhia das Letras. 1996.

CÓDIGO DE POSTURAS...

Codigo de Posturas da Illustrissima Camara

Municipal do Rio de Janeiro e Editaes da mesma Camara. Rio de Janeiro: Eduardo \& Henrique Laemmert. 1870.

COELHO, Edmundo Campos.

As profissões imperiais: medicina, engenharia e advocacia no Rio de Janeiro (1822-1930). Rio de Janeiro: Record. 1999.

DIAS, Maria Odila Leite da Silva.

Quotidiano e poder em São Paulo no século XIX. São Paulo: Brasiliense. 1984.

DOCUMENTOS...

Documentos referentes a gêneros alimentícios. Códice 59-1-46 (Arquivo Geral da Cidade do Rio de Janeiro). 1880-1889.

DOCUMENTOS...

Documentos referentes ao comércio de gêneros alimentícios comércio de leite. Códice 59-1-17 (Arquivo Geral da Cidade do Rio de Janeiro). 20 jan. 1884.

\section{DOCUMENTOS...}

Documentos referentes a gêneros alimentícios. Códice 59-1-45 (Arquivo Geral da Cidade do Rio de Janeiro). 1850-1879.

DOCUMENTOS...

Documentos referentes ao comércio de gêneros alimentícios comércio de leite. Códice 58-4-45 (Arquivo Geral da Cidade do Rio de Janeiro). 1850-1879.

DOCUMENTOS...

Documentos referentes à infração de posturas e multas da freguesia de Santana. Códice 9-2-19 (Arquivo Geral da Cidade do Rio de Janeiro). jul. 1865 .

\section{DOCUMENTOS...}

Documentos referentes à infração de posturas da freguesia do Sacramento. Códice 9-1-43 (Arquivo Geral da Cidade do Rio de Janeiro). 22 jan. 1842.

FOUCAULT, Michel. Microfísica do poder. Rio de Janeiro: Graal, 1985.

GOUVÊA, Maria de Fátima.

Poder, autoridade e o senado da câmara do Rio de Janeiro, ca.1780-1820. Tempo, Niterói, v.7, n.13, p.111-155. 2002. 
GOUVÊA, Maria de Fátima.

Redes de poder na América portuguesa: o caso dos homens bons do Rio de Janeiro, ca. 17901822. Revista Brasileira de História, São Paulo, v.18, n.36, p.297-330. 1998.

HERSCHMANN, Micael; KROPF, Simone; NUNES, Clarice.

Missionários do progresso: médicos, engenheiros e educadores no Rio de Janeiro (1870-1937). Rio de Janeiro: Diadorim. 1996.

HOLLOWAY, Thomas.

Polícia no Rio de Janeiro: repressão e resistência numa cidade do século XIX. Rio de Janeiro: Fundação Getulio Vargas. 1997.

MATTOS, Ilmar Rohloff de.

O tempo saquarema: a formação do Estado imperial. São Paulo: Hucitec. 2004.

MONTEIRO, Nuno Gonçalo.

Os concelhos e as comunidades. In: Hespanha, Antonio Manoel (Coord.). História de Portugal. O Antigo Regime (1620-1807). Lisboa: Estampa. v.4. 1998.

PEREIRA, Magnus Roberto de Mello.

Almuthasib: considerações sobre o direito de almotaçaria nas cidades de Portugal e suas colônias. Revista Brasileira de História, São Paulo, v.21, n.42, p.365-395. 2001.
SAMPAIO, Gabriela dos Reis.

Nas trincheiras da cura: as diferentes medicinas no Rio de Janeiro imperial. Campinas: Editora da Unicamp. 2001.

SILVA, Antonio Simões da.

Relatório enviado ao ministro da Justiça,

Eusébio de Queirós Coutinho Matoso. Série

Secretaria de Polícia da Corte; maço IJ6-212 (Arquivo Nacional). 13 nov. 1849.

SOUZA, Iara Lis Carvalho.

A pátria coroada: o Brasil como corpo político autônomo (1780-1831). São Paulo: Unesp. 1999.

SOUZA, Juliana Teixeira.

A autoridade municipal na Corte imperial: enfrentamentos e negociações na regulação do comércio de gêneros (1840-1889). Tese (Doutorado em História) - Universidade Estadual de Campinas, Campinas. 2007.

THOMPSON, Edward Palmer. Costumes em comum: estudos sobre a cultura popular tradicional. São Paulo: Companhia das Letras. 2002.

THOMPSON, Edward Palmer. Senhores e caçadores: a origem da Lei Negra. Rio de Janeiro: Paz e Terra. 1997. 